\title{
Faulty fetal packing
}

\author{
Christopher Flannigan, Conor O’Neill
}

Department of Paediatrics, Antrim Area Hospital, Antrim, UK

Correspondence to Dr Christopher Flannigan, cflannigan@doctors.org.uk

\section{Summary}

A male infant was born by emergency caesarean section at $34^{+4}$ weeks for failed induction of labour. Shortly after birth a depression about the same size as the baby's fist was noted over the right parietal region. After careful consideration of the perinatal history and examination findings, the baby was diagnosed with faulty fetal packing. At 3-month follow-up, the defect had completely corrected without intervention.

\section{BACKGROUND}

Faulty fetal packing occurs in 1 in 10000 births, ${ }^{1}$ however, it is often not recognised and misdiagnosed as a depressed skull fracture. In this case report, we discuss how to confidently differentiate between these two conditions.

\section{CASE PRESENTATION}

A male infant was born by emergency caesarean section at $34^{+4}$ weeks for failed induction of labour. The indication for induction of labour was preterm prolonged rupture of membranes of $479 \mathrm{~h}$ and reduced liquor volume.

The mother was a 38-year-old woman, para 2, with no significant medical history and there had been an uneventful singleton pregnancy.

During the caesarean section, there was significant blood loss and the baby required extensive resuscitation including the administration of $\bigcirc$ negative blood. After stabilisation, the baby was transferred to the neonatal unit for further management.

At this stage, a depression (about the same size as the babies fist was noted) over the right parietal region. There was no surrounding bruising or oedema. As this was initially felt to represent a ping-pong fracture, a skull x-ray (figure 1) was performed.

The clinical history was discussed with the radiology team, as the baby had been born by caesarean section without the use of instruments and as there was no signs of acute injury (absence of soft tissue swelling or bruising) the appearance was felt to be more in keeping with a congenital vault depression related to in utero positioning. The long duration of prolonged rupture of membranes and oligohydramnios may have been a contributing factor.

\section{OUTCOME AND FOLLOW-UP}

The baby was followed up in the neonatal clinic at 3 months of age where the skull defect was noted to have completely corrected without any intervention and the baby was developmentally appropriate for age.

\section{DISCUSSION}

Faulty fetal packing, also known as a congenital vault depression, occurs in 1 in 10000 births. ${ }^{1}$ As the fetus' bones are easily deformable, external pressure can result in a depression of the soft bones of the skull without causing a break in the cortex. Recognised causes of a congenital vault depression include the compressing force of a bony prominence of the pelvis, a uterine fibroid and the fetus' own hand or foot or the body part of a twin. ${ }^{2}$

The radiological appearance in a congenital vault depression is very similar to what is seen in a depressed or pingpong skull fracture, however, the two conditions have a very different aetiology. In contrast to a congenital vault depression, a ping-pong skull fracture is an acute injury normally caused by obstetric manoeuvres during a difficult delivery. ${ }^{3}$ Therefore, differentiation between these two conditions relies more on careful consideration of the

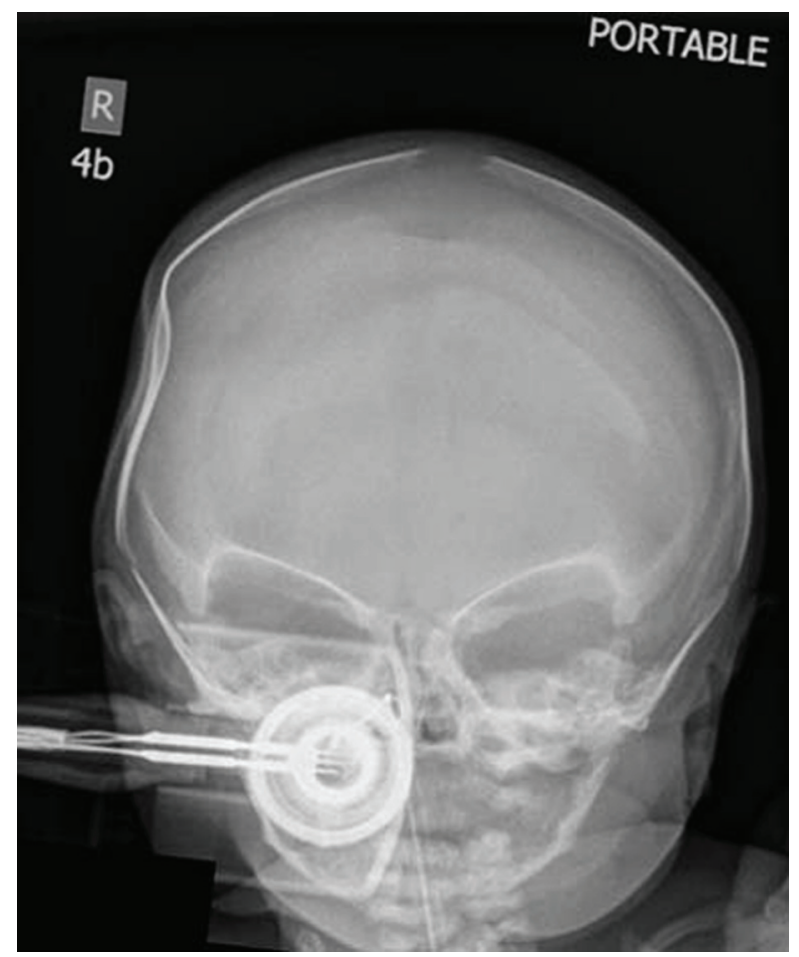

Figure 1 AP skull $x$-ray showing a well-defined depression in the right parietal region, without any overlying soft tissue swelling. 


\section{BMJ Case Reports}

perinatal history and clinical examination than on radiological findings.

Treatments that have been used successfully in faulty fetal packing include surgical elevation, manual elevation using digital pressure at the sides of the depression, suction elevation with a breast pump or vacuum

\section{Learning points}

- Faulty fetal packing, also known as a congenital vault depression, occurs in 1 in 10000 births. $^{1}$

- The radiological appearance in faulty fetal packing is very similar to what is seen in a depressed skull fracture and differentiation between the two conditions relies more on careful consideration of the perinatal history and clinical examination than on radiological findings.

- In faulty fetal packing, a full and spontaneous resolution of the depression often occurs over the first few months of life, without leaving any cosmetic or neurodevelopmental sequelae. extractor. ${ }^{2}$ However, as this case and a number of other case reports $^{4-6}$ have shown a full and spontaneous resolution of the depression often occurs over the first few months of life, without leaving any cosmetic or neurodevelopmental sequelae, so simple observation is our preferred approach.

\section{Competing interests None.}

Patient consent Obtained.

\section{REFERENCES}

1. Ben-Ari Y, Merlob P, Hirsch M, et al. Congenital depression of the neonatal skull. Eur J Obstet Gynecol Reprod Biol 1986;22:249-55.

2. Williams H. Lumps, bumps and funny shaped heads. Arch Dis Child Educ Pract Ed 2008;93:120-8

3. Mastrapa TL, Fernandez LA, Alvarez MD, et al. Depressed skull fracture in Ping Pong: elevation with Medeva extractor. Childs Nerv Syst 2007:23:787-90.

4. Hanlon L, Hogan B, Corcoran D, et al. Congenital depression of the neonatal skull: a self limiting condition. Arch Dis Child Fetal Neonatal Ed 2006;91:F272.

5. Tavarez LA, Kottamasu SR, Ezhuthachan SG, et al. Neonatal skull depression: review of four cases. J Perinatol 1989:9:423-6.

6. Eisenberg D, Kirchner SG, Perrin EC. Neonatal skull depression unassociated with birth trauma. AJR Am J Roentgenol 1984;143:1063-4.

This pdf has been created automatically from the final edited text and images.

Copyright 2011 BMJ Publishing Group. All rights reserved. For permission to reuse any of this content visit

http://group.bmj.com/group/rights-licensing/permissions.

BMJ Case Report Fellows may re-use this article for personal use and teaching without any further permission.

Please cite this article as follows (you will need to access the article online to obtain the date of publication).

Flannigan C, O'Neill C. Faulty fetal packing. BMJ Case Reports 2011;10.1136/bcr.02.2011.3802, date of publication

Become a Fellow of BMJ Case Reports today and you can:

- Submit as many cases as you like

- Enjoy fast sympathetic peer review and rapid publication of accepted articles

- Access all the published articles

- Re-use any of the published material for personal use and teaching without further permission

For information on Institutional Fellowships contact consortiasales@bmjgroup.com

Visit casereports.bmj.com for more articles like this and to become a Fellow 